\title{
Role of the Injection Water Microorganisms on Corrosion of Fiberglass in TFT Algerian Oil Fields
}

\author{
S. Kebbouche-Gana and M.L. Gana
}

\begin{abstract}
The most severe corrosion due to bacterial activity in pipe steel for the transportation of water and the injection systems is influenced by sulphate reducing bacteria (SRB), thiosulphate reducing bacteria (TRB) and others microorganisms. In the aim to reduce the impact of bacterial corrosion, steel pipes were substituted by fiberglass pipes. These types of materials are very resistant to corrosion and the life of use was prolonged. Fiberglass pipes are used for the water transportation that be used for the water flooding systems in the oil fields and fire systems. During the opening of a section of the fiberglass line, the scale found inside this line, produced a smoke that was followed by a fire that provoked the inflammation of the fiberglass. Also, the aim is to understand the phenomena and a suspicion of the role of some bacteria in this phenomenon. The identified bacteria in all the samples show the presence of sulfate-reducing bacteria, methanogenic bacteria and fermentative bacteria. We think that by synergic effect, the growth of these microorganisms transform heavy organic molecule to methane and others chemicals species. The methane is gas and under the effect of the sun may start fire.
\end{abstract}

Keywords - corrosion, Fiberglass pipes, biofilms, methanogens, sulfate reducers bacteria)

\section{Introduction}

Fibreglass reinforced plastics (FRP) based on epoxy, vinyl ester and unsaturated polyester resins are extensively used in corrosion applications because of their relatively good corrosion resistance in different aqueous environments (1). It is widely used in oil industry and gas gathering system and water injection pipeline. Compared with the traditional steel pipe, fiberglass has many different outstanding advantages, such as excellent corrosion resistance, which solves the problem of the steel pipe corrosion and offers excellent resistance against corrosive environments including, salt water, $\mathrm{H}_{2} \mathrm{~S}$ and chemical applications. The weight of fiberglass is only $1 / 3$ of the steel tube, which facilitates the installation; also inner wall of fiberglass is very smooth with great hydraulic performance and a small friction coefficient which makes wax and scaling process difficult (2). Among the oil fields in the world using the maintenance of pressure, the TFT (Tin Fuin Tabankort) oilfield located in the south-Eastern Algerian Sahara is operated by Sonatrach Company.

Salima Kebbouche-Gana

Laboratoire Conservation et Valorisation des Ressources Biologiques, Faculté des Sciences,

Université M'Hamed Bougara de Boumerdes - Avenue de

l'Indépendance - 35000 - Algérie

Mohamed. Lamine Gana

Centre of Research and Development, Biocorrosion Laboratory,

SONATRACH, Avenue of 1st November, 35000 Boumerdes, Algeriar
Generally, oil fields are one of the deep geological environments that support the existence of microorganisms. They occur at significant subsurface depth and are characterized by a high in situ temperature. Physiological types of microorganisms that have been isolated from these biotopes include heterotrophs (3), sulfate reducers (4), sulfidogens (5), fermentative bacteria (6), manganese and iron reducers (7), methanogens (8), acetogens (9) and many more. Most of them are anaerobes; Pyrococcus and Thermococcus spp. have been found in oil reservoirs (10). Both of them derive energy by fermentation of peptides, amino acids, and sugars, forming fatty acids, $\mathrm{CO}_{2}$, and $\mathrm{H}_{2}$ (11).

Adding, the major autotrophs recovered from water flooding include isolates closely related to Methanobacterium, Methanococcus, and Methanoculleus species and Desulfomicrobium, suggesting the widespread distribution of sulfur-utilizing and methane-producing thermophilic microorganisms in some oil reservoirs (12). Noting that the methanogenic bacteria are a large and diverse group that is united by three features, they are members of the domain Archaea, they are strict anaerobes, and they form large quantities of methane as the major product of their energy metabolism. The major substrates are $\mathrm{H}_{2}+\mathrm{CO}_{2}$, formate, and acetate. Likewise, many methanogens are unable to utilize oxidized sulfur compounds. Because the most widely used sulfur source, sulfide, reacts chemically with oxygen, anaerobiosis is also required to protect the sulfur source in the medium (13). Indeed, the fiberglass surfaces are rapidly colonized by anaerobic and aerobic bacteria present in the bulk liquid phase. The first step of the above mentioned biological sequence is the development of a thin film on the material surface.

The film is formed by inorganic ions and high molecular weight organic compounds that alter the electrostatic charge and wettability of the materiel surface. At a more advanced stage, bacterial colonization leads to the growing of a biofilm mainly consisting of water, bacterial cells and extracellular polymeric substances (E.P.S.). These microorganisms involved in the corrosion processes are numerous and have many possible mechanisms of attack on the material. In anaerobic conditions, the microorganisms present in the fiberglass lines are almost exclusively bacteria (14).

The order in which the cells are layered is determined by the order in which the substrate is consumed, which ensures that the outermost cells have direct access to fresh nutrients from the medium, and the cells in the more inward layers have access to the products made by the more outward layers. During methanogenesis the layered 
Proc. of the Third Intl. Conf. Advances in Bio-Informatics, Bio-Technology and Environmental Engineering- ABBE 2015 Copyright (c) Institute of Research Engineers and Doctors, USA .All rights reserved.

ISBN: 978-1-63248-060-6 doi: 10.15224/ 978-1-63248-060-6-01

structure helps to keep the hydrogen concentration low as the intermediate product $\mathrm{H}_{2}$ acts as an inhibitor (15).

Channels are formed in the biofilms/aggregates to aid the removal of gaseous products. Layered structures are mainly formed at high nutrient concentrations; at lower concentrations a clustered structure is more beneficial as the surface area for transfer to the clustered cells is increased (16). However, microbial production of gases (such as methane and carbon dioxide) is an important activity for the self ignition of fiberglass lines. Since, the methane gas concentration reaches the critical level required for ignition. Better understanding and controlling of corrosion behavior of fiberglass can increase application range and therefore having a large economic impact. Consequently, in this paper, TFT oilfield environment was simulated. We have first incriminated the metabolic role of specific bacterial species and made a microbiological analysis of the biofilms collected from the coupons mounted in corrosion loop.

\section{Materials and Methods}

\section{A. Biofilm establishment and system conditions}

Injection water was obtained from the TFT oilfield. In situ, the injected water temperature is between $47^{\circ} \mathrm{C}$ and $50^{\circ} \mathrm{C}$. All experiments were, therefore, conducted at $37 \pm 1{ }^{\circ} \mathrm{C}$. Water injection for flooding and pressure support is a key element in oil-fields operations. Table 1 presents chemical composition of injection water sample coming from the Algerian Sahara oil-field using in this study.

Biofilms were grown inside an onshore water injection transported into the fiberglass line of fire water systems. Removable fiberglass coupons $\left(0.2-\mathrm{cm}^{2}\right.$ surface area) made from the same structural pipeline material were mounted in corrosion loop (CL) to facilitate in Laboratory sampling of biofilms grown on the coupons 'Fig.1.'.

In this study, the composition of E-glass is built from $54 \%$ of $\mathrm{SiO}_{2}, 14 \%$ of $\mathrm{Al}_{2} \mathrm{O}_{3}, 22 \%$ of $\mathrm{CaO}+\mathrm{MgO}, 10 \%$ of $\mathrm{B}_{2} \mathrm{O}_{3}$ and less than $2 \%$ of $\mathrm{Na}_{2} \mathrm{O}+\mathrm{K}_{2} \mathrm{O}$. This glass is a super-cooled mixture of metallic oxides. It is brittle and transparent but has a very high tensile strength; $3400 \mathrm{MPa}$ (500 ksi) (2). On each of the 7 days after the incubation period which lasted 3 months, one biofilm-covered coupon of fiberglass was collected from the corrosion loop (CL) and rinsed by swirling them in phosphatebuffered saline (PBS) solution three times to remove loosely attached cells. Each coupon was removed and placed in an Eppendorf tube with $1.0 \mathrm{ml} \mathrm{PBS}$. Tubes were kept in an ice bath. The coupons were then sonicated using an ultrasonic cleaner for $7 \mathrm{~min}$ and vortexed for $9 \mathrm{~s}$ to remove biofilms from the coupons. Suspensions from the biofilms were used for bacterial enumeration. In this study, the composition of E-glass is built from $54 \%$ of $\mathrm{SiO}_{2}, 14 \%$ of $\mathrm{Al}_{2} \mathrm{O}_{3}, 22 \%$ of $\mathrm{CaO}+\mathrm{MgO}, 10 \%$ of $\mathrm{B}_{2} \mathrm{O}_{3}$ and less than $2 \%$ of $\mathrm{Na}_{2} \mathrm{O}+\mathrm{K}_{2} \mathrm{O}$. This glass is a supercooled mixture of metallic oxides.

TABLE I. CHEMICAL COMPOSITION OF INJECTION WATER SAMPLE COLLECTED FROM TFT OILFIELD

\begin{tabular}{|c|c|c|c|c|c|c|c|}
\hline Element & $\mathrm{Ca}^{2+}$ & $\mathrm{Fe}^{2+}$ & $\underset{+}{\mathrm{Mg}^{2}}$ & $\mathrm{~K}^{+}$ & $\mathrm{Na}^{+}$ & $\mathrm{Ba}^{2+}$ & $\mathrm{HCO}_{3}$ \\
\hline $\begin{array}{l}\text { Conc. } \\
\text { (mg/L) }\end{array}$ & $\begin{array}{c}187 . \\
3\end{array}$ & 0.1 & $\begin{array}{c}163 . \\
4\end{array}$ & 39.1 & 300.1 & 0.0 & 165.9 \\
\hline Element & $\mathrm{PO}_{3}{ }^{2}$ & $\mathrm{NH}_{4}^{-}$ & $\underset{2-}{\mathrm{NO}_{3}}$ & $\mathrm{NO}_{2}^{-}$ & $\mathrm{CO}_{3}{ }^{2-}$ & $\mathrm{Cl}^{-}$ & $\mathrm{SO}_{4}{ }^{2-}$ \\
\hline $\begin{array}{l}\text { Conc. } \\
\text { (mg/L) }\end{array}$ & 4.3 & 11.0 & 33.5 & 11.6 & 0.0 & 670.9 & 600.1 \\
\hline
\end{tabular}

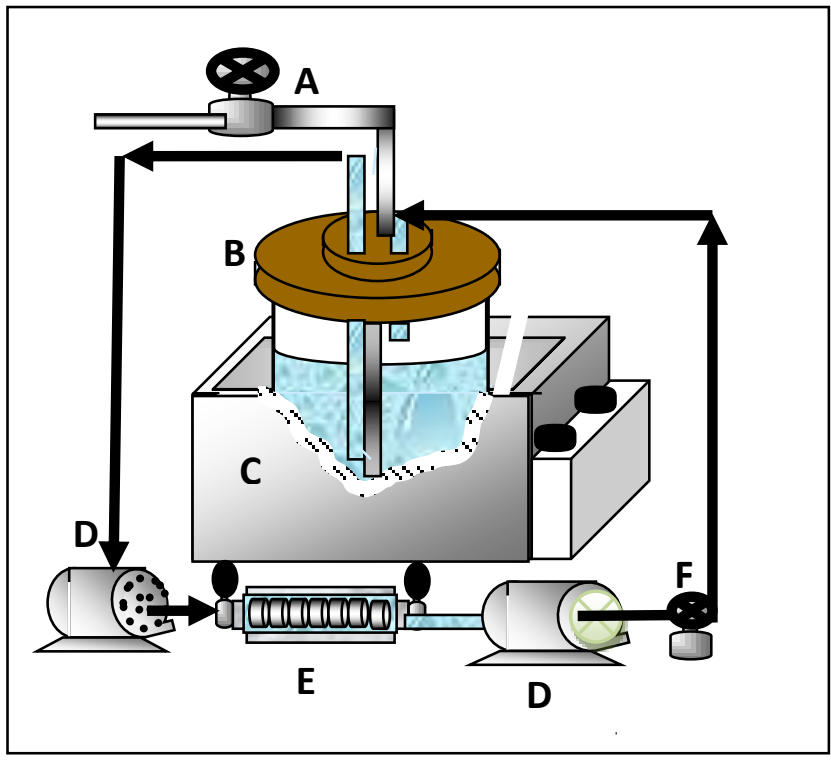

Figure 1. Schematic diagram of the experimental using fiberglass coupons in the corrosion loop (CL).

(A): Input nitrogen gas, $(\mathrm{B}): \mathrm{O}_{2}$ was removed from the water after nitrogen injection, (C) Heated compartment (D): pumps for circulation, (E) Positions of fiber glass coupons in the injection water deoxygenated system, (E): Sampling point

It is brittle and transparent but has a very high tensile strength; $3400 \mathrm{MPa}$ (500 ksi) (2). On each of the 7 days after the incubation period which lasted 3 months, one biofilm-covered coupon of fiberglass was collected from the corrosion loop (CL) and rinsed by swirling them in phosphate-buffered saline (PBS) solution three times to remove loosely attached cells. Each coupon was removed and placed in an Eppendorf tube with $1.0 \mathrm{ml}$ PBS. Tubes were kept in an ice bath. The coupons were then sonicated using an ultrasonic cleaner for $7 \mathrm{~min}$ and vortexed for $9 \mathrm{~s}$ to remove biofilms from the coupons. Suspensions from the biofilms were used for bacterial enumeration.

\section{B. Media composition and bacterial enumeration}

Suspensions from the coupons obtained after each week of the overall period of the experiment were first fixed with paraformaldehyde (PFA) (2\% final conc., 
adjusted to $\mathrm{pH}$ 7.4). Within $2 \mathrm{~h}$ after fixation, samples were filtered onto white polycarbonate filters (pore size, $0.2 \mu \mathrm{m}$ ), washed twice with phosphate-buffered saline (PBS) buffer ( $\mathrm{pH} 7.6)$, dried, and stored at cool until further processing. Total cell numbers were determined by epifluorescence counting after staining with 4', 6diamidino-2-phenylindole (DAPI) as previously described (17).

A viable count of SRB and methaogenic bacteria was determined by the enumerations method using a medium as described below. The anaerobic technique described by Balch and Wolfe (18) was used throughout the study.

The medium used for the enumerations of methanogenic bacteria consisted of the following components (mM): $\mathrm{KH}_{2} \mathrm{PO}_{4} \quad(2.94), \mathrm{K}_{2} \mathrm{HPO}_{4} \quad$ (1.15), $\mathrm{NH}_{4} \mathrm{Cl}$ (9.35), $\mathrm{NaCl}$ (10.27), $\mathrm{MgCl}_{2}$ (0.5), $\mathrm{CaCl}_{2}$ (0.34), $\mathrm{Na}_{2} \mathrm{~S}(0.5)$, resazurin $(0.003)$, acetate $(30.0) ; 10 \mathrm{~mL} / \mathrm{L}$ of trace element solution (19) was used. The media contained antibiotics, kanomycin and streptomycin at a concentration of $60 \mu \mathrm{g} / \mathrm{ml}$.

The methanogens are resistant to antibiotics. The medium used for the enumeration of SRB consisted of the following components (mM): $\mathrm{KH}_{2} \mathrm{PO}_{4}$ (2.94), $\mathrm{K}_{2} \mathrm{HPO}_{4}$ (1.15), $\mathrm{NH}_{4} \mathrm{Cl}$ (9.35), $\mathrm{NaCl}$ (10.27), $\mathrm{MgCl}_{2}$ (0.5), $\mathrm{CaCl}_{2}$ (0.34), $\mathrm{Na}_{2} \mathrm{SO}_{4}(20.0), \mathrm{Na}_{2} \mathrm{~S}(0.5)$, resazurin (0.003), lactate $(30.0) ; 10 \mathrm{~mL} / \mathrm{L}$ of trace element solution $(19,20)$ was used. The population sizes of microorganisms of the main metabolic groups were determined by inoculation of suspensions from the biofilms into liquid nutrient media in a series of tenfold dilution. The numbers of aerobic organotrophs were determined in liquid medium containing the following $(\mathrm{g} / \mathrm{L}$ distilled water): Bacto tryptone, 5.0; yeast extract, 2.5; glucose, 1.0; sodium chloride, $5.0 ; \mathrm{pH} 7.0$.

Anaerobic organotrophs with fermentative metabolism were enumerated in medium with peptone (4 $\mathrm{g} / \mathrm{L})$ and glucose $(10 \mathrm{~g} / \mathrm{L})$ supplemented with $\mathrm{Na}_{2} \mathrm{SO}_{4}(2$ $\mathrm{g} / \mathrm{L}), \mathrm{MgSO}_{4}$ (1 g/L), and Mohr's salt (0.5 g/L). The gaseous phases were as follows: for aerobic bacteria, air; for hydrogen consuming methanogens, $\mathrm{H}_{2}+\mathrm{CO}_{2}(4: 1$, $\mathrm{vol} / \mathrm{vol})$ mixture. The cultures were incubated at $37^{\circ} \mathrm{C}$ for 30 days. All media contained $2 \%$ agar were autoclaved at $121^{\circ} \mathrm{C}$ for $15 \mathrm{~min}$. The bacterial counts in the suspensions from the biofilms were determined in duplicate by using the agar shake dilution method (21-22).

\section{Results and Discussion}

The total cells enumerated by epifluorescence microscopy after DAPI staining varied from $0,9 \times 10^{5}$ to $90 \times 10^{5}$ cells $/ \mathrm{mL}$ from 1 st to the 12 th week the incubation period. These abundance levels are not within the range of those previously reported ''Fig.2'.

Thus, according to Tang and Cooney (23) the development of biofilm on different materials total counts on three materials (stainless steel, aluminum and fiberglass) without a coating reached a maximum in 24-
$96 \mathrm{~h}$ and the number remained stable for the remainder of the 6-plus-day incubation period.
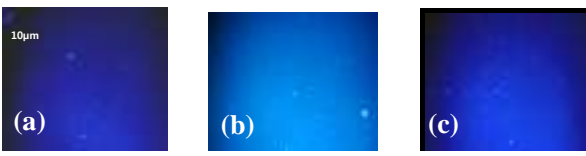

Figure 2. Fluorescence microscopy images of bacteria obtained in suspensions resulting from a biofilm incubated for (a) 1 week, (b) 2 weeks and (c) 3 weeks stained with DAPI

The predominant microorganisms in the suspensions obtained from the coupons are bacilli and diplobacilli. So, the viable counts of biofilms on stainless steel were almost 10 -fold higher than those on aluminum and fiberglass.

Cell numbers were 10 to 100 fold higher for total counts than viable counts, suggesting that a large number of cells in the film were dead or viable but- non-culturable on the coupon surfaces "'Fig.3",

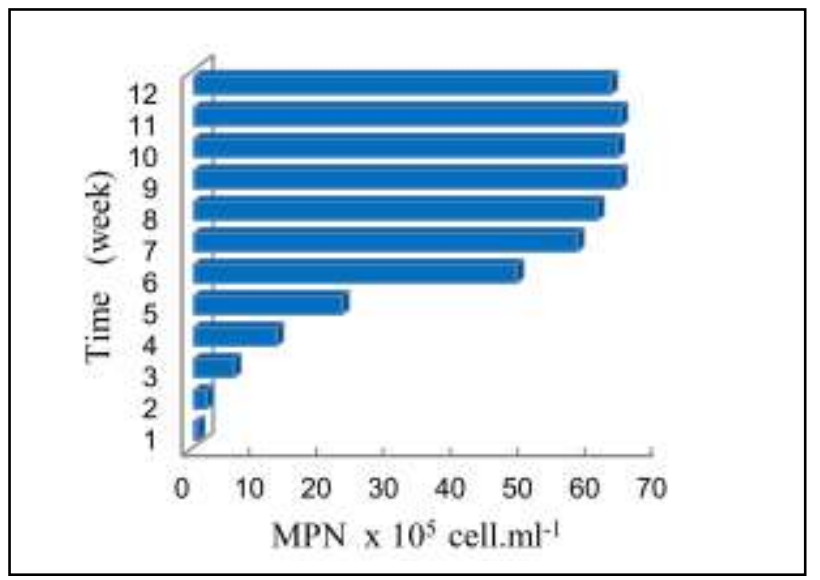

Figure 3. Direct counts from biofilms grown on the surface of fiberglass coupons.

The salinity of the injection water contained $2,51 \mathrm{~g} / \mathrm{L}$. and its $\mathrm{pH}$ varied from 7.1 to 7.3 . The biofilm samples were collected from 3 different periods and it is interesting to note that the biofilm from fiberglass showed significant methanogenesis and the organism was isolated from this biofilm. So, in the first month, the number of culturable aerobic organotrophs and anaerobic microorganisms with fermentative metabolism were below 60 cells $/ \mathrm{mL}$.

The numbers of sulfate reducing prokaryotes were predominant in the samples, and their numbers were $15,5 \times 10^{1}$ cells $/ \mathrm{mL}$ and methanogens were below 25 cells/mL 'Fig.4.'. However, there were no significant methanogenic activities in the biofilms of fiberglass. In the laboratory that both sulfate-reducing bacteria and methanogenic bacteria are capable of using $\mathrm{Fe} \sim$ and other elemental metals $(24,25)$ as a source of hydrogen for growth and metabolism "Fig.5.". After the second month of the incubation, in biofilms, the environment is largely anaerobic even with only a thin film established. So, we isolated methanogenic bacteria from this biofilm. It is also likely that $\mathrm{H}_{2}$ is produced in the biofilms by the activities of other heterotrophic bacteria present in the biofilm, and this $\mathrm{H}_{2}$ is used by the methanogens (26). 


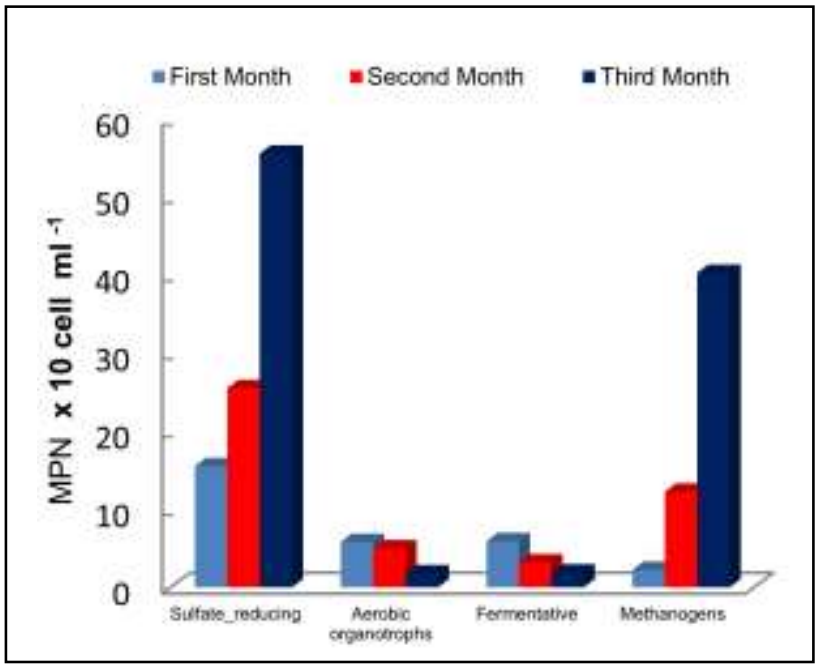

Figure 4. Bacterium enumeration groups obtained from biofilms grown on the surface of fiberglass coupons after 3 periods of time

First, Sulfate Reducing Bacteria (SRB) are anaerobic and the most distributed in industrial systems, they exist in crude oils, in fuels and in water. They accelerate the reducing of sulphates $\left(\mathrm{SO}_{4}{ }^{2-}\right)$ contained in aqueous solution into sulphides $\left(\mathrm{S}^{2-}\right)$ which attack support. Secondly, microorganisms producing acids acetogens (27) which are usually heterotrophic bacteria, fungi, sulphur oxidizing bacteria, and bacteria oxidizing ammonia $\left(\mathrm{NH}_{3}\right)$ to nitric acid $\left(\mathrm{HNO}_{3}\right)$. These microorganisms play essential role in corrosion of metals in crude oil, fuels, soil, and water. However, acidproducing bacteria are very dangerous to concrete, some polymers, and fiberglass.

In this study, in the presence of important quantity of sulfate, sulfate-reducing bacteria utilize $\mathrm{H}_{2}$ at concentrations lower than the minimum concentration which can be utilized by methanogens (28). Presumably, the ability of the sulfate-reducing bacteria to outcompete the methanogens is a direct consequence of the more positive reduction potential of $\mathrm{SO}_{4}{ }^{2-}$ compared to that of $\mathrm{CO}_{2}$. In addition to these chemical interactions, direct contact of the cells also plays an important part in mixedspecies biofilms. Interspecies electron transfer is known to be important during anaerobic degradation of organic or inorganic matter to methane.

During this process, close physical contact between syntrophs and methanogens is required. In environments with sufficient quantities of sulfate, hydrogen sulfide is the predominant reduced product, and the major fate of biodegradable organic carbon is oxidation to $\mathrm{CO}_{2}$. If sulfate becomes limiting, methane replaces hydrogen sulfide as the reduced product, and the organic carbon is disproportionated to $\mathrm{CO}_{2}$ and methane.

It should be mentioned in this case, the sulphur oxidizing bacteria (no enumerate in this study) which are aerobic bacteria deriving energy from the oxidation of elemental sulphur and its compounds (for example, hydrogen sulphide, or other sulphur-containing substances) to sulphates $\left(\mathrm{SO}_{4}{ }^{2-}\right)$. They are responsible for acid mine drainage, proliferate inside sewer lines, and when produce sulphuric acid (up to $10 \mathrm{wt} \%$ ), are very dangerous to steels, copper, aluminum, zinc, in short, to all. Sulphur oxidizing bacteria are almost always accompanied by sulfate-reducing bacteria, pipelines can be attacked by these microorganisms. So, fiberglass has a good anti-pressure ability, quick and easy in thread connection.
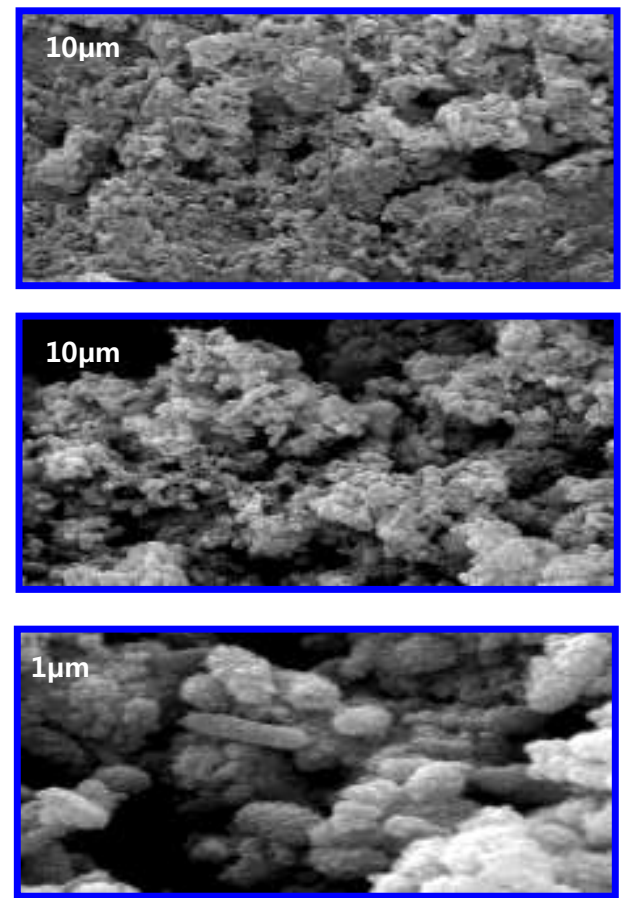

Figure 6. Scanning electron micrographs image of Biofilms on the surface of fiberglass after 4 weeks.

However, inorganic compounds in crudes inorganic chloride salts $\left(\mathrm{NaCl}, \mathrm{MgCl}_{2}, \mathrm{CaCl}_{2}\right)$, hydrogen sulphide $\left(\mathrm{H}_{2} \mathrm{~S}\right)$ and elemental sulphur $\left(\mathrm{S}^{2-}\right)$ are main corrosive species in crudes. Chloride salts when they are present in aqueous solution in two-phase crude-water system may become which can be responsible for $\mathrm{H}_{2} \mathrm{~S}$ production, which causes 'souring' of the crude oil; by biofilm proliferation. The presence of the biofouling influences the fiberglass biodegradation (29).

Furthermore, in their study, Qiu and Kumosa (30) describe the corrosion effect of E-glass fibers exposed to oxalic, hydrochloric, nitric and sulfuric acids. The results reveal that acid corrosion of E-glass fibers is primarily attributed to calcium and aluminum ion depletion.

According Bounoughaz and Touabi (31) studied the phenomenon of self ignition of the fiberglass pipes used for transportation of water exploited to maintain the pressure in the oil field of Zarzaitine (Region of in Amenas located in the south of Algeria). The obtained results revealed the presence of a heterogeneous microbial population with a high concentration level of sulfatereducing bacteria (SRB), methanogenic bacteria (MB), yeasts and fungi. The interaction between the different species of bacteria and the organic matter contained in the deposits has generated the formation of methane which under the influence of the great heat burnt and the fire caused the ignition of the fiberglass line. 
Proc. of the Third Intl. Conf. Advances in Bio-Informatics, Bio-Technology and Environmental Engineering- ABBE 2015 Copyright (C) Institute of Research Engineers and Doctors, USA .All rights reserved.

ISBN: 978-1-63248-060-6 doi: 10.15224/ 978-1-63248-060-6-01

\section{Conclusion}

In some fields, fiberglasses are the most widely applied non-metallic pipes in Algeria. They have been used extensively in systems water injection wells and subsurface facilities, where the environment contains lots of corrosive media such as $\mathrm{CO}_{2}, \mathrm{H}_{2} \mathrm{~S}, \mathrm{SO}_{4}{ }^{2-}$ and $\mathrm{Cl}^{-}$. These substances are often the microbial metabolites of crude oil -water, combined with free water and can cause severe corrosion problems in oil and gas pipelines, even in the fiberglass. In these environments, the salt solution, the diverse temperature, the different $\mathrm{CO}_{2}$ partial pressure and $\mathrm{H}_{2} \mathrm{~S}$ partial pressure give rise to an unknown corrosion behavior of fiberglass. In this study the obtained results revealed the presence of a heterogeneous microbial population with a variable concentration level of sulfatereducing bacteria, methanogenic bacteria, and aerobic organotrophs and fermentative. The interaction between the different species of bacteria and the organic matter contained in the water has generated the formation of metabolites like $\mathrm{H}_{2} \mathrm{~S}$ and methane which under the influence of the great heat burnt and the fire caused the ignition of the fiberglass line.

\section{References}

[1] C. Alzieu, Environmental problems caused by TBT in France: assessment, regulations, prospects. Marine Environ Res.1991, 32, pp. 7-17.

[2] L. Chen, S. Wu, H. Lu, K. Huang and J. Shi, Comparative analysis of FRP and seamless steel pipe on crude oil transportation performance. J. Chem. Pharm. Res., 2014, 6(7), pp.2364-2369.

[3] JL. DiPippo, CL. Nesbo, H. Dahle, WB. Doolittle, N-K. Birkland, KM. Noll, Int J Syst Evol Microbiol, 2009, 59, pp. 2991-3000.

[4] E. Miranda-Tello, ML. Fardeau, J. Sepúlveda, L. Fernández, J.L Cayol, P. Thomas, B. Ollivier, Int J Syst Evol Microbiol, 2003, 53, pp.1509-1514.

[5] S. L'Haridon, AL. Reysenbach, BJ. Tindall, P. Schönheit, A. Banta, U. Johnsen, P. Schumann, A. Gambacorta, E. Stackebrandt, C. Jeanthon, Int J Syst Evol Microbiol, 2006, 56, pp. 2843-2852.

[6] E. Miranda-Tello, Fardeau M-L., C. Joulian, M. Magot, P. Thomas, JL. Tholozan, B. Ollivier, Int J Syst Evol Microbiol, 2007, 57, pp.40-44.

[7] AD. Greene, BKC. Patel, AJ. Sheehy, Int J Syst Bacteriol, 1997, 47, pp.505-509.

[8] L. Cheng, TL. Qiu, XB. Yin, XL. Wu, GQ Hu, D. Yu, H. Zhang, Int J Syst Evol Microbiol, 2007, 57, pp. 2964-2969.

[9] IA. Davydova-Charakhchyan, AN. Mileeva, LL. Mityushina, SS. Belyaev, Mikrobiologiya, 1993, 61, pp. 306-315.

[10] KO. Stetter, R. Huber, E. Blochl, M. Kurr, RD. Eden, M. Fielder, Nature, 1993, 365, pp.743-745.

[11] G. Fiala, KO Stetter, HW. Jannasch, TA Langworthy, J. Madon, Syst Appl Microbiol, 1986, 8, pp.106-113.

[12] VJ. Orphan, LT. Taylor, D. Hafenbradl, EF. Delong, Appl Environ Microbiol, 2000, 66, (2), pp.700-711.

[13] K. Bleicher, G. Zellner, J. Winter, Growth of methanogens on cyclopentanol/ CO2 and specificity of alcohol dehydrogenase, FEMS Microbiol Lett, 1989, 59, pp.307-312.

[14] R. Vismara, Depurazione biologica, Ed. Hoepli, WG. Characklis, Fouling biofilm development: a process analysis, Biotech. Bioeng., 1982, 23, pp. 1923-1960.

[15] HA. Widela, Biological corrosion and biofilm effects on metal biodeterioration. In C.E.O'Rear, G.C. Liewellyn (Eds), Biodeterioration Research 2, Plenum Press, New York, 1989, pp.39-50.
[16] KG. Porter et YS Feig, The use of DAPI for identifying and counting aquatic microflora. Limnol. Oceanogr , 1989, 25, pp. 943-948.

[17] WE Balch, RS Wolfe, New approach to the cultivation of methanogenic bacteria: 2-mercaptoethane sulfonic acid (Hs$\mathrm{CoM}$ ) dependent growth of Methanobacterium ruminantium in a pressurized atmosphere, Appl Environ Microbiol, 1976, 32, pp.781-791.

[18] L. Daniels, N. Belay, BS. Rajagopal, BS, Assimilatory reduction of sulfate and sulfite by methanogenic bacteria. Appl Environ Microbiol, 1986, 51, pp. 703-709.

[19] N. Belay, KY. Jung, BS. Rajagopal, JD Kremer, L. Daniels, 1990, Nitrate as a sole nitrogen source for Methanococcus thermolithotrophicus and its effect on growth of several methanogenic bacteria, Curr Microbiol, 1990, 21, pp.193198.

[20] WB. Whitman, TL. Bowen, DR. Boone, The methanogenic bacteria. In: Balows A, Trupper HG, Dworkin M, Hardner W,Schleifer KH (eds) The prokaryotes. New York: Springer, 1992, pp. 719-767.

[21] CL. Willis, GR. Gibson, C. Allison, S. Macfarlane, JS. Holt, Growth, incidence and activities of dissimilatory sulfate reducing bacteria in the human oral cavity, FEMS Microbiol Lett, 1995, 129, pp.267-272.

[22] RJ. Tang and JJ. Cooney, Effects of marine paints on microbial biofilm development on three materials, Journal of Industrial Microbiology \& Biotechnology, 1998, 20, pp. 275-280.

[23] N. Belay, L. Daniels Elemental metals as electron sources for biological methane formation from $\mathrm{CO} 2$, Antonie Van Leeuwenhoek, 1990, 57, pp.1-7.

[24] L. Daniels, N. Belay, BS. Rajagopal, PJ. Weimer Bacterial methanogenesis and growth from $\mathrm{CO}_{2}$ with elemental iron as the sole source of electrons, Science, 1987, 237, pp. 509-511.

[25] R. Boopathy, L. Daniels Pattern of organotin inhibition of methanogenic bacteria, Appl Environ Microbiol 57, 1991, pp. 1189-1193.

[26] IA Davydova-Charakhchyan, AN. Mileeva, LL. Mityushina, SS. Belyaev, Mikrobiologiya 61, 1993, pp. 306-315.

[27] JK. Kristjansson, P. Schonheit, RK. Thauer Different K, Values For Hydrogen Of Methanogenic Bacteria And Sulfate Reducing Bacteria, Arch Microbiol, 1982, 131, pp. 278-282.

[28] DR. Lovley, Minimum threshold for hydrogen metabolism in methanogenic bacteria. Appl Environ Microbiol, 1985, 49, pp.1530-1531.

[29] MP. Mouritz, AG. Gibson, Fire properties of polymer composite materials. Dordrecht: Springer; 2006.

[30] Q. Qiu and M. Kumosa, 1997, Corrosion of E-glass Fibers in Acidic Environments. composites Science \& Technology, 1997, 57, 5 pp. 497-507.

[31] M. Bounoughaz, N. Touabi, The self ignition of fiberglass lines, International Letters of Chemistry, Physics and Astronomy, 2014, 20 (1), pp. 1-9.

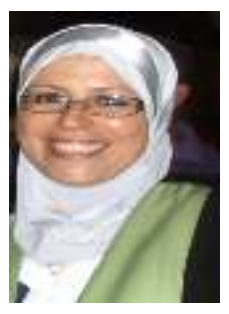

Kebbouche-Gana Salima has obtained postdoctoral degree from university of Sciences and Technologies Houari Boumediene (Algeria). She is the Head of team: Microbial biodiversity and biotechnology (Bmbeap). She has published more than 10 papers in reputed journals.

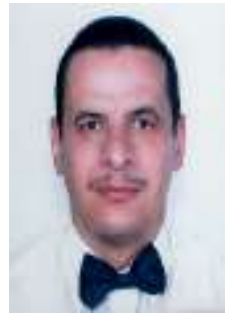

Mohamed Lamine Gana has obtained postdoctoral degree from Polytechnic National School University. He is the Head Department of Biocorrosion Laboratory in the Research and Development Center, Sonatrach, Avenue 1er Novembre, 35000 Boumerdes, Algeria. 